\title{
日本脊骾外科学会の歩みと諸課題
}

\section{History and Agenda of the Japanese Society of Spinal Surgery}

\author{
花 北順 哉
}

Junya Hanakita, M.D.

\section{Key words}

history, spinal surgery, agenda

\section{はじめに}

本稿は, 飛驒一利会長のもとに開催された第 30 回日本 春髄外科学会において行われた, 日本脊髄外科学会 30 周 年特別企画「脊髄外科学会の歩み」での講演内容に基づ いている。この講演での演者であった阿部 弘先生・金 彪先生の講演内容と一部重複する部分が存在することに ついては御了承いただきたい.

本稿では, 阿部 弘先生の講演内容を踏まえたうえ で，前半部分では，私が本学会の理事・理事長時代に取 り組んできた項目として，1．認定医・指導医制度の設立 と運営，2．学会の法人化，3. 整形外科学会との共通の 専門医制度策定に向けての協議の開始，につき記述す る. 後半部分では, 従来から私が常に提唱してきたいく つかの課題につき記載する。

\section{1. 認定医・指導医制度の設立と運営}

\section{1) 日本脳神経外科学会における脊髄・脊椎外科の 位置づけについて}

わが国に扔ける脳神経外科の発展の歴史を紐解いてみ ると，一般外科から独立した診療科として「脳神経外科」 が公式に認められたのは，昭和 40 年（1965 年）6月 19 日付官報においてである。その目指すところは「脳，せ き髄及び末しょう神経に関する外科」と高らかに謳われ ている。しかしながら，今日にいたるまで「脳神経外科」 と正式に呼ばれることは少なく、「脳外科」あるいは「脳
外」と呼ばれていることが多い，すなわち，「脳神経外科 医はアタマ医者」との思い込みが，わが国国民の中に刷 りこまれた誤解であり，残念なことにこの思い込みは， 医療界でもいまだ根深いものがあるのが現状である.

一方，国際的な観点から眺めると，脊髄・脊椎疾患が 脳神経外科領域において占める割合は 60～70\% とされ ている，現時点でわが国に扔けるこの比率は $17 \%$ 程度で あり，まだまだこの分野の拡張が望まれるところである。

\section{2 ）認定医・指導医制度の立ち上げ}

このような状況にあったために，脊髄外科学会主導の もとに脊髄外科認定医・指導医制度を設立すべきである との考えにいたった。この設立に際しては，当時，北海 道大学脳神経外科の助教授であった岩崎喜信先生（現北 海道大学名誉教授）と私が中心となり，綿密な検討を重 ねていった。この制度の目的は大きく分けて 2 つり， 第 1 の目標は, 一般脳神経外科医に対して, 脊髄・脊椎 疾患について学習する機会を保障することであり，もう 1つの目標は，春髄・春椎分野を一生のメインテーマと する脳神経外科医を育成し，その技量の質を高めること とした。しかしながら，この認定医制度の設立準備段階 に打いて多方面から反対意見が表明された。そのうちの 二，三のものを挙げてみると，脳神経外科医の担当領域 を狭めてしまうことになる，脳神経外科医が脊髄を扱う のは当たり前ではないか，欧米の脳神経外科ではこのよ うな subspeciality としての専門医制度はみられない, 等々であった。

藤枝平成記念病院脊髄脊椎疾患治療センター／Spinal Disorders Center, Fujieda Heisei Memorial Hospital 連絡先：干426-8662 藤枝市水上 123-1 藤枝平成記念病院脊䯣脊椎疾患治療センター 花北順哉 〔Address reprint requests to： Junya Hanakita, M.D., Spinal Disorders Center, Fujieda Heisei Memorial Hospital, 123-1 Mizukami, Fujieda-shi, Shizuoka 4268662, Japan] 
しかしながら，われわれの立場としては，日本の現状 を冷静に眺めてみて, 脳神経外科は建前では, 脳・脊 髄・末梢神経など神経に関するあらゆる疾患を対象とす ると謳われながら，現状ではあまりにも頭蓋内疾患に偏 在した治療しか行ってこなかったこと, 指導すべき医師 が脊髄・脊椎分野の治療経験がなければ，後に続く若い 脳神経外科医も当然この領域の治療を行う機会がないこ とから，この制度の設立に向けて精力的に取り組み, 2003 年に発足するにいたった。

\section{3）日本脊髄外科学会の脊髄外科認定医・指導医制 度の特徵}

設立にあたって，この制度では認定医と指導医の 2 段 構えの制度とすることとした，特に，脊髄外科指導医に は単なる手術技量のみでなく, アカデミックな資質を要 求することとした。この目指すところは, 指導医の役目 は自己の臨床レベルを高めるだけでなく, 後進の指導を 十分に行うことにあると考えたからである。この制度の 発足以来, 指導医の資格の取りにくさが指摘されている が, ほとんどの場合，アカデミックな面での活動，すな わち学会発表・論文発表のスコアが不足することに起因 している，指導医たるもの手術の技量が優れているのは 当然であり, それに加えて学会活動・執筆活動を自ら行 い後進の指導能力を備えているべきと考えるからである.

\section{4 ）認定医・指導医制度の現況と課題}

2015 年 4 月の時点で, 認定医 341 名, 指導医 80 名, 訓練施設 29 施設となっている。 ちなみに訓練施設とは, 指導医が在籍し, その施設に 1 年間在籍すれば, 認定医 合格相当の臨床経験が獲得できるほどの症例数の豊富な 所となっている.

2003 年に発足し運営してきたこの認定医・指導医制度 の課題としては, 認定医・指導医の分布に顕著な地域的 偏りがみられることである。この偏りは，わが国におけ る医師の偏在をある程度反映したものではあるが，これ にも増して偏在の傾向が強い. 学会として何らかの有効 な対策を講じる必要があると考える。制度のほかの課題 としては，指導医のもと・訓練施設で行われてきた指 導・教育内容の検証である. 発足後 12 年を経過した制度 であるが，目標がどの程度達成されたのかの検証・解決 すべき問題点の洗い出しなどを行う段階にあると考える.

\section{2. 複数の臨床科にまたがる sub- specialityにおける共通の専門 医制度の設立}

この項目に関しては，現在金 彪理事長のイニシアチ ブのもとに日本脊椎脊髄病学会と鋭意協議中であり, 金 先生が詳述されることと思うので，ごく簡潔に述べるに 留めたい.

日本専門医制評価・認定機構（現在の日本専門医機構） では, 複数の臨床科にまたがる subspeciality の 1 つし て, 脊椎・脊髄分野が考えられていた。この機構のもと で共通の専門医制度の設立に参加できる資格としては,

(1)学会が法人化されていること, (2)独自の専門医制度を すでに運営していること，(3)それぞれの親学会がその領 域を重要な一分野であると認知していること，などが要 求された。

専門医制度に関しては前述のようにわが学会はすでに 設立・運営していたが，ほかの要件を満たすべく，学会 の法人化を行い(この作業に関しては事務局長である大 畑建治先生と学会事務局スタッフの多大な働きに負うと ころが多かった), また日本脳神経外科学会本体と数度 の話し合いを行い，認知していただいた．

近い将来, 日本脊椎脊髄病学会とわれわれ日本脊髄外 科学会に共通の専門医制度が発足することとなるが, 機 構の要求する 3 要件が満たされていなかった場合には, われわれ脳神経外科医が脊髄・春椎分野で大手を振って 活躍することができなかった可能性もあり，多くの反対 にもかかわらず専門医制度を立ち上げて，運営してきて よかったと考えている。

後半では，従来からことあるごとに私が表明してきた 諸課題について触れてみる。

\section{I 、脊髄疾患における画像診断学の 過去・現在・未来}

わが国の脳神経外科医は前述のごとく脊髄・脊椎疾患 について経験することが少なかったために，この分野の 画像診断の過去についても知る人はかなり限られている と思う。しかしながら，この歴史はわれわれ臨床家に とっては重要な教訓を含んでいると考えるために，ここ で記載することとする。

まずは，「油性造影剤による脊髄造影」であり，「神経 毒性の強い水溶性造影剤」に関してである。昭和 40～50 年代はじめ頃までは, CT scan はもちろん, MRIの開 
発・導入以前の時期であり, 春髄疾患の診断において最 も有力な診断方法は油性造影剂による脊髄造影であっ た。この造影剂はくも膜下腔から吸収排泄されることが ないために, 注入し，しかるべき撮影をした後に回収す る必要がある造影剤であった。しかしながら，この回収 手技が困難で, 時には造影剂が生涯にわたってくも膜下 腔や頭蓋底脎槽部に遺残することとなった，現在でも， 60 歳代以降の患者の腰椎単純撮影や頭蓋骨撮影におい て㑒柱管内や頭蓋底部に多数の斑点状陰影として認める ことがある. 油性造影剤の使用経験のない若い医師の中 には, この所見に対して脊柱管内の異常石灰化・頭蓋底 の寄生虫などの診断をつける者も時に見受けるが，これ は脊椎くも膜下腔や脳底槽部に遺残した油性造影剤であ る.これが注入後数十年を経過して, きわめて難治性の 癒着性くも膜炎を引き起こしてくることがある。 ほとん どの治療に抵抗性の疼痛であり, 頭蓋内では視交叉部の くも膜炎から失明にいたることもある。この時代では, 検査法としてはこれしかなく，使わざるを得なかったも のであるが，生体内に残った異物が数十年経過して災い をもたらし得る例として, 脊髄外科医としては心に留め ておくべきことの1つである.

この油性造影剤の後に開発されたものが, 現在でも使 用されている水溶性造影剂である，この造影剂は，注入 後ある時間経過後腎から排泄されるために回収の必要は ない。ただし, 初期の水溶性造影剤は神経刺激性・毒性 が強いものであった，脊髄造影後の激しい頭痛・嘔吐は ほぼ必発の副作用であり, 時には全身けいれん・意識障 害・急激な痴呆症状を呈することもあった。臨床に使用 されているさまざまな薬剤・器具は必ずしも安全なもの ではないことを若い医師達には伝えておきたい．

昭和 50 年代 (1970 年代中頃) に, CT scan 次いで MRI が頭蓋内・脊髄・脊椎疾患の診断に導入されるように なった。この両機器の開発・導入は脊䯣・春椎疾患の診 断における画期的な出来事であり，これにより患者が受 けた恩恵は計り知れないものがある. しかしながら,こ れらの導入以降, 医師達の神経学的診断能力は著明に低 下した，神経学の面白さとは詳細な病歴聴取と綿密な神 経学的検査, 自分のもっている神経学に関する知識を組 み合わせて，局在診断を下すにいたるということに尽き ると思うが, この楽しみを現在の若い医師達は惜しいこ とに十分には味わっていないように思われる。患者の話 をろくに聞かずに，診察も扔ざなりに済ませ，もっぱら MRI 画像を眺めている医師が多い.ひどい場合には, MRI 所見のみから手術適応まで決めている医師も見受 けられる。このような脊髄外科医にはなってほしくない
ものである.

脊髄疾患の画像診断の将来に期待するものはいくつか あるが，その 1 つは，脊髄循環障害の画像化である。い くつかの試みがなされつつあるが, 現時点では解像度が あまりにも低く，信頼に足るものとはなっていない，画 像診断における何らかの breakthrough が望まれるとこ ろである。また，脊髄障害が何ゆえに生じているのかを 説明できる画像の提示, すなわち春髄機能障害の画像 化・機能形態学といった面での開発も将来への期待とし て述べて㧍きたい，個人的には，痛みの可視化も実現し てほしい課題である。これは fMRI などのさらに一段の 工夫などにより実現可能なテーマではないかと期待して いる.

\section{II. 脊髄・脊椎外科の過去・現在・ 未来}

脊髄・脊椎外科の発達に大きく関与した事象として は,「戦時における外傷外科」と「カリエスに対する宜椎 外科」がある，現在われわれが行っている手術のほとん どのものは, これら 2 つのものに抏いて開発され導入さ れた術式である，機会があれば，古い文献などを紐解い て先人たちの奮闘の跡を訪ねてみることを就すすめする.

現在の脊椎外科は, 脊椎変性疾患に対するものが主体 となっている。 さまざまな手術法・固定法が考案されて いるが，適応には種々の見解があり，いずれが優れてい るのかに関してはいまだ結論は出ていない.

わが国脳神経外科医が行う手術手技のほとんどのもの は, 手術用顕微鏡下に行うマイクロサージャリーであ り, 脊髄・脊椎疾患に対してもこれが採用されている. 春椎領域へのマイクロサージャリーの応用は 1977 年頃 に Yasargil, Casperらによりはじめられた。現在これが 導入されてほぼ 40 年を経過しているが, 果たしてこれを 超えるものは何か？というのが1つの課題である. 内視 鏡下手術であるのか? ロボットサージャリーであるの か？現時点の両者の内容では，まだまだマイクロサー ジャリーを凌ぐほどのものは得られていないと考える. ヒトが自らの手を使って行う手技の発展という面から考 えた場合, 外科医の到達点としてマイクロサージャリー はあるいは頂点で, これ以上のものは将来にわたって出 ないのではないかとも考えられる，たとえば，世界に冠 たる日本刀を取り上げてみると，この刀の製作技術は室 町時代に確立され，それ以降連綿として伝承されてきた ものに則って今でも日本刀は製作されているとのことで ある，現在われわれが行っているマイクロサージャリー 
の技量もこのようなものとなるのか否か，興味がある課 題である.

現在の脊椎外科では内固定器具・いわゆる instrumentation を使用する手技がかなりのものを占めているが, この手技は多くの課題を抱えている。まずは，この instrumentation の適応が不明確である点である。そもそ も春椎変性疾患に対して, 除圧術のみでよいのか・除圧 に何らかの固定術を加えるのがよいのか・固定に際して instrumentation を併用するのがよいのか否か，に関して エビデンス・コンセンサスが得られていない，また，現 在行われている内固定器具のほとんどのものは自家骨移 植を併用して強固な椎体間固定を目指寸ものであるが, この場合には元来は何らかの動きを有する脊柱の動きを 止めるという非生理的な行為であり，必然的に隣接椎間 障害の危険をはらんでいる。 また，各種素材でつくられ た固定器具を長期にわたって生体内に放置した場合の影 響については，現在のところまったくわかっていない．

外科の歴史を振り返って眺めてみると，われわれ外科 医は自らが行う手術の長期の結果について必ずしも明確 な予想が立たない術式を採用して, 後になって悲惨な結 果をもたらしたという苦い経験を重ねてきている。この ような一世を風靡しながらも後世になって厳しい指弾を 受けた諸手術の代表的な例としては, schizophreniaに対 する lobotomy がある。これを開発した脳神経外科医は ノーベル賞を受賞したが、これを受けた多くの患者は akinetic mutism の状態となり,この手術を行った世界中 の脳神経外科医の心に深い傷跡を残した。この術式が脳 神経外科医に与えたダメージは計り知れないものがあ り，いまだ psychosurgeryが本格的に取り組まれていな い理由の 1 つとなっている.

Lobotomy ほどには指弾されることはなかったが，苦 い教訓を後の外科医に残した術式も数多くある。一般外 科の領域でもたとえば，肺結核に対する外科治療として 胸郭形成術なるものが行われていた時代に, 胸腔内にピ ンポン玉を充填する術式が開発された。従来の胸郭形成 術では複数本の肋骨を骨折せしめて肺の呼吸活動を制限 させるために，術後の側弯・姿勢異常などの美容面での 不具合が必発であった。ピンポン玉充填術は胸郭の変形 をきたすことなく結核病変がコントロールされ，救命に つながった点では，優れた術式ではあった。しかしなが ら, 術後数十年して胸腔内に留置したピンポン玉が化膿 巣となり, きわめて摘出が困難な膿胸を発症することと なった，生体内に留置された異物が，術後長期間経過後 に誠に面倒な反応をもたらす可能性があることを示唆す る教訓的な事例である。
われわれ脳神経外科医が比較的最近身近に経験したも のとしては，屍体から採取した硬膜を使用した症例に発 生したCreutzfeldt-Jakob 病の症例群がある。生体内に使 用・留置する材料の長期に及ぼす影響については未知の 感染症・いまだ想定し得ない出来事が出現する危険性は つねにあり得ることを外科医は肝に銘じなければならな w.

脊髄・暙椎外科医が常日頃使用している spinal instrumentationは果たしていかがであろうか？ 特に懸念され るのは vital organ の近傍に設置されたままになっている 器具, 特に食道近傍に用いられる䅡椎椎体プレートとス クリューであり，大動脈の近傍に用いられる胸椎椎体ス クリューであろう，前者では，スクリューの破損・逸脱 による食道損傷・頚動脈破裂などが報告されていたが, 長年の経過中，スクリューの破損や逸脱のない症例でも 食道穿孔が出現した症例が報告されている。あくまで, 各種の椎体固定器具は骨性癒合が完成するまでの仮固定 の役目を果たすものであり，骨性癒合が完成した段階で 可能な限り抜去することが望ましい，それにも増して， 内固定器具の使用に際してはその適応は十分過ぎるほど 限定的なものに留めるべきであると考える.

\section{III. わが国脳神経外科医が行ってい る脊髄・脊椎手術について}

わが国脳神経外科の全手術数に対する脊髄・春椎手術 の割合については過去に 4 回の全国規模の調查が行われ ている. 1996 年, 2000 年, 2004 年, 2012 年度に扔ける それぞれの割合は， $5.9 \% ， 8.2 \% ， 8.6 \% ， 17.6 \%$ となって いる. 前述のごとくこの比率は欧米では 60〜 70\%となっ ており，まだまだ低い数值にとどまっている。一方，21 世紀になってからの脳神経外科の分野別手術件数の伸び 率という観点から眺めてみると，2001 年度と 2007 年度 における伸び率では，第 1 位を占める血管内手術の $77.5 \%$ という伸び率に次いで, 脊髄・春椎分野は $56.6 \%$ と第 2 位の伸び率を示す分野となっている。この伸び率 から判断するに, 今後わが国脳神経外科の臨床の力点が 脊髄・春椎分野に注がれることは容易に想像できる。

脊髄・春椎手術の部位別頻度の变遷を眺めてみると, 1996 年度の調査では, 頚椎 : 胸椎 : 腰椎の頻度が $66 \%$, 7\%，27\%であったものが，2004 年度の調査ではこの比 率が，53\%：1\%：46\%となって拈り，腰椎疾患に対する 比率が増加している. 将来的には澒椎 : 腰椎の比率は 1 : 3 となると考えられる。 今後, 脊髄・春椎外科を志寸脳 神経外科医は, 腰椎変性疾患に対する診断能力・治療能 
力を身につけておく必要がある。具体的には, 腰椎レべ ルに生じる各種病態の理解と保存的療法の習熟・確実で 安全な除圧術と固定術の修得が要求される。

\section{IV. 整形外科医（脊椎外科医）との 関係・脳神経外科医が目指す道 について}

脊髄・脊椎分野の治療においては, わが国では先行す るきわめて強力で優秀な勢力としての整形外科医（脊椎 外科医）達がいる。彼らは, 長年の臨床経験を有してお り素晴らしい研究成果を発表してきている。学会規模で のマンパワーもわれわれの 3 倍はあり, 基礎的研究に関 しても, 春髄損傷・脊髄再生・バイオメカニクスなど幅 広い分野での研究を長年にわたって遂行している。これ に対して, 脳神経外科医の行う春髄・脊椎外科分野にお ける臨床研究はまだまだ不十分であり, 脊椎外科で必要 とされる術後の長期成績に関する報告も残念ながら脳神 経外科サイドからはほとんど出ていないのが現状であ る. 基礎的研究の面ではいくつかの大学で取り組まれて いるが，そのほとんどのものは春髄損傷・再生をテーマ とするものに留まっており, 守備範囲の狭さは否めない.
「基礎的研究の裏づけのない, 単なる手術手技に終始 する外科領域には将来はない」ということを, これから 脊髄・脊椎外科を志す後輩たちには是非伝えておきたい と思う。確かにわれわれ脳神経外科医は若い頃から手術 用顕微鏡下での手術手技の習得に長年心血を注いでお り，それなりの成績は挙げてきたと思う。これは誇る心゙ きことである。しかしながら，現在では若手の整形外科 医達はすでにマイクロサージャリーを十分に修得しつつ あり，立派な成績を挙げるようになってきている，今後， 春椎外科医がマイクロサージャリーに十分精通したとす れば，果たして脊髄・春椎分野におけるわれわれ脳神経 外科医の raison d'être は何であろうか? 若い人々への 宿題として投げかけてみたいと思う。

本原稿の執筆中に, 三重大学 $\mathrm{OB}$ の久保和親先生が本 年 2 月 5 日に急逝された.

久保先生においては，脊髄外科学会に多大の貢献をさ れ, 数多くの後進達を教育してこられたが, 特に本稿で 記載した「脊髄外科認定医・指導医制度」の立ち上げ・ 運営に際しては大変なご協力をいただいた。臨床家とし ての抜群のセンスと技量を有した優れた脊髄外科医を失 い，まことに残念なことである。

ここに，先生のご冥福を㧍祈り申し上げる。 